\title{
KORELASI ANTARA KONDUKTIVITAS AIR LAUT DENGAN JUMLAH MINERAL TERLARUT PADA PERAIRAN SELAT MADURA
}

\section{CORRELATION BETWEEN SEAWATER CONDUCTIVITY AND AMOUNT OF DISSOLVED MINERALS IN MADURA STRAIT WATERS}

\author{
Hari Prihatno, Rizal F. Abida, \& Sophia L. Sagala \\ Pusat Riset Kelautan, BRSDM KP, KKP, Jakarta \\ Jalan Pasir Putih II, Lt. 4, Ancol Timur, Jakarta Utara, 14430 \\ e-mail : hari.prihatno@gmail.com
}

Diterima tanggal: 10 Mei 2021 ; diterima setelah perbaikan: 06 Desember 2021 ; Disetujui tanggal: 10 Desember 2021

\begin{abstract}
ABSTRAK
Penelitian ini bertujuan untuk menganalisis jumlah mineral terlarut (Total Disolved Solid/TDS) berdasarkan data konduktivitas (Electrical Conductivity/EC) pada perairan Selatan pulau Madura. Data EC diperoleh dari pengukuran in-situ pada 24-26 April 2013. Penelitian ini dilakukan di perairan Selat Madura pada $7^{\circ} 18^{\prime} 53,1^{\prime \prime} \mathrm{LS}-$ 78'58, '"LS dan $113^{\circ} 11^{\prime} 43,4$ " BT-11356'14'BT, yang memiliki karakteristik berbeda sesuai dengan keadaan sekitarnya. Perhitungan korelasi antara salinitas dan EC sebesar 0,64, yang diperoleh melalui uji statistik dan menjadi acuan sebagai penentu tingkat kandungan TDS pada keseluruhan badan perairan Selat Madura. Berdasarkan perhitungan kandungan TDS di Selat Madura berkisar antara 33,8 - 35,1 ppm. Hasil analisis diperoleh bahwa tingkat salinitas mempengaruhi daya hantar listrik, serta salah satu komponen dari mineral terlarut merupakan garam-garam yang terdapat pada air laut, hal ini dapat dibuktikan bahwa semakin tinggi tingkat salinitas maka semakin tinggi pula kandungan mineral terlarutnya.
\end{abstract}

Kata Kunci : Konduktivitas, EC, Jumlah mineral terlarut, Selat Madura.

\begin{abstract}
The study was aimed to investigate the amount of organic and inorganic materials (total dissolved solids/ $T D S$ ) dissolved in the southern coastal waters of Madura islands. TDS data was derived from conductivity data obtained from in-situ measurements in Madura Strait waters on April 24-26, 2020. The survey area was

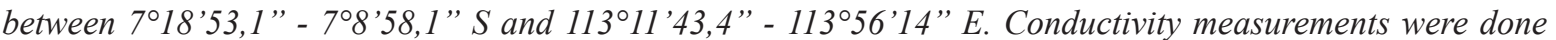
with purposive sampling method based on the characteristic of the sampling locations. From a single factor ANOVA statistical correlation analysis on salinity and electrical conductivity, a coefficient of 0.64 with $p=0.33$ is obtained, suggesting an insignificant difference exists. The results were further then used as a reference in determining the TDS level in the studied area. The results showed that total dissolved solids at the sampling sites of Madura Straits ranged from 33.8-35.1 ppm. The analysis results indicated that salinity contribute to the electrical conductivity of the solution, in this case, the conductivity is obtained from the presence of minerals and salts dissolved in sea water. This suggests the linear correlation between salinity and TDS, i.e. the higher the salinity indicates the higher the amount of dissolved minerals in seawater. Thus, it can be summarized that the salinity can be used to predict the amount of mineral dissolved in the coastal waters.
\end{abstract}

Key Word : Conductivity, Electrical Conductivity, Total Dissolved Solid, Madura Strait.

Korelasi antara Konduktivitas air laut dengan Jumlah Mineral Terlarut pada Perairan Selat Madura - Hari Prihatno, Rizal F. Abida, \& Sophia L. Sagala 


\section{PENDAHULUAN}

Air laut memiliki kadar garam karena bumi dipenuhi dengan garam mineral yang terdapat di dalam batubatuan dan tanah. Contohnya Natrium, Kalium, Kalsium, dll. Keberadaan garam-garaman mempengaruhi sifat fisis air laut (seperti: densitas, kompresibilitas, titik beku, dan temperatur dimana densitas menjadi maksimum) beberapa tingkat, tetapi tidak menentukannya. Beberapa sifat (viskositas, daya serap cahaya) tidak terpengaruh secara signifikan oleh salinitas. Dua sifat yang sangat ditentukan oleh jumlah garam di laut (salinitas) adalah daya hantar listrik (konduktivitas) dan tekanan osmosis (Litaay et al. (2014)).

Konduktivitas air dapat dinyatakan dalam satuan $\mu \mathrm{mhos} / \mathrm{cm}$ atau Siemens $/ \mathrm{cm}$. Air tanah dangkal umumnya mempunyai harga 30-2000 $\mu \mathrm{mhos} / \mathrm{cm}$. Konduktivitas air murni berkisar antara 0-200 $\mu \mathrm{S} / \mathrm{cm}$ (low conductivity), konduktivitas sungai sungai besar/ major berkisar antara 200-1000 $\mu \mathrm{S} / \mathrm{cm}$ (mid range conductivity), dan air saline adalah 1000-10000 $\mu \mathrm{S} / \mathrm{cm}$ (high conductivity). Nilai konduktivitas untuk air layak minum sekitar 42-500 $\mu \mathrm{mhos} / \mathrm{cm}$. Nilai konduktivitas lebih dari $250 \mathrm{mhos} / \mathrm{cm}$ tidak dianjurkan karena dapat mengendap dan merusak batu ginjal (Afrianita et al. (2017); Gasim et al. (2015)).

Konduktivitas (Daya Hantar Listrik/DHL) menurut Khairunnas \& Gusman (2018), adalah gambaran numerik dari kemampuan air untuk meneruskan aliran listrik. Oleh karena itu, semakin banyak garam-garam terlarut yang dapat terionisasi, semakin tinggi pula nilai DHL. Beberapa faktor lain yang mempengaruhi nilai kondutivitas adalah kandungan litologi, keadaan batuan, kandungan mineral, komposisi objek cair dan sebab eksternal sebagainya. Konduktivitas dinyatakan dengan satuan $\mu \mathrm{mhos} / \mathrm{cm}$, dapat dideteksi dengan menggunakan alat EC meter (Elektric Conductance). Pengukuran daya hantar listrik bertujuan mengukur kemampuan ion-ion dalam air untuk menghantarkan listrik serta memprediksi kandungan mineral dalam air. Lebih lanjut Siosemarde et al. (2011) mengungkapkan bahwa konduktivitas merupakan kemampuan air untuk menghantarkan aliran listrik, dan ion-ion terlarut dalam air tersebut merupakan konduktornya. Ion utama bermuatan positif adalah Natrium (Na), Kalsium $(\mathrm{Ca})$, Kalium (K), dan Magnesium (Mg). Ion utama bermuatan negatif adalah Klorida (Cl), Sulfat (S), Karbonat, dan Bikarbonat.

Total Dissolved Solid (TDS) menunjukkan jumlah unsur terlarut baik organik maupun non organik dalam air. TDS dapat menimbulkan warna, rasa dan bau yang tidak sedap. Beberapa senyawa kimia pembentuk TDS bersifat karsinogenik. TDS berbanding lurus dengan turbiditas, konduktivitas dan salinitas (Mutmainah \& Adnan (2018)). Nurrohim et al. (2012) menyebutkan bahwa air laut memiliki nilai Total Disolved Solid (TDS) yang tinggi karena banyak mengandung senyawa kimia, yang juga mengakibatkan tingginya nilai salinitas dan daya hantar listrik. Mineral yang terlarut yang terdiri atas garam anorganik dan bahan organik direpresentasikan sebagai Jumlah mineral terlarut (TDS). Anorganik TDS merupakan gabungan dari enam ion utama, seperti kalsium, magnesium, bikarbonat, sodium, klorida dan sulfat. Bahan organik terkandung juga dalam TDS pada BOD dan COD (Thirumalini \& Joseph (2008)). Dalam literature yang lain Siosemarde et al. (2011), juga mengatakan bahwa mineral yang ditemukan di alam dalam bentuk terlarut terdiri atas garam anorganik dan bahan organik yang terwakili dalam bentuk jumlah mineral terlarut.

Salinitas menurut Effendi (2003) dalam Izati \& Syech (2020), merupakan kepadatan kandungan jumlah ion garam berada pada perairan laut. Kaitannya antara salinitas dan TDS adalah garam merupakan mineral anorganik yang terlarut dalam air laut sebanding dengan TDS, sesuai persamaan 1.

Salinitas $\sim$ TDS

Salinitas dapat menunjukkan kondisi TDS, mengingat salinitas merupakan parameter yang menunjukkan kadar garam terlarut. Sementara TDS juga menunjukkan padatan yang terlarut di dalam air, dalam hal ini TDS merupakan sebagian besar padatan yang terlarut (garam terlarut).

Berdasarkan persamaan 2, secara umum hubungan antara TDS dengan konduktivitas adalah TDS mengandung garam yang memiliki kemampuan untuk menghantarkan arus listrik.

$\operatorname{TDS}(\mathrm{mg} / \mathrm{L})=\mathrm{kEC} \cdot \operatorname{Konduktivitas}(\mathrm{dS} / \mathrm{m})$

dimana,

$\mathrm{kEC}=$ koefisien konduktivitas

Data Konduktivitas (Electrical Conductivity (EC)) akan menunjukkan kemampuan air untuk menghantarkan aliran listrik. Konduktivitas air bergantung dari konsentrasi ion dan temperatur air, oleh karena itu kenaikan padatan terlarut akan 
mempengaruhi kenaikan nilai EC (McNeely et al. (1979)). Nilai EC dipengaruhi oleh:

- Konsentrasi ion : semakin tinggi konsentrasi ion maka nilai konduktivitas elektrik semakin tinggi.

- Temperatur larutan : semakin tinggi temperatur larutan maka nilai konduktivitas elektrik semakin tinggi.

- Sifat dasar ion : semakin tinggi kemampuan spesifik dan valensi ion maka nilai konduktivitas elektrik semakin tinggi.

EC dapat digunakan sebagai pengganti pengukuran TDS. pengukuran TDS menggunakan EC lebih cepat dan lebih bermanfaat dibandingkan pengukuran menggunakan gravimetry. Pengukuran TDS menggunakan EC lebih efektif dibandingkan dengan pengukuran laboratorium (Shirokova et al. (2000)). Disebutkan pula oleh Effendi (2003), bahwa hubungan antara TDS dan EC adalah fungsi dan jenis dari kation dan anion yang terlarut dalam air. Keterkaitan antara TDS dengan EC tidak linier, hal ini disebabkan oleh bervariasinya kecepatan konduktivitas masing-masing ion.

Berdasarkan asumsi di atas maka tujuan dari penelitian ini adalah mengetahui jumlah mineral terlarut (TDS) ditinjau dari korelasinya terhadap data salinitas dan konduktivitas hasil pengukuran insitu di perairan selat Madura.

\section{BAHAN DAN METODE}

Data yang digunakan adalah data konduktivitas dan salinitas yang diperoleh dari pengukuran in-situ menggunakan alat CTD 12 Plus Applied System, yang diambil pada 24 hingga 26 April 2013, di perairan Selat Madura sesuai yang ditunjukkan pada Gambar 1. Metode pengambilan data konduktivitas dilakukan secara purposive sampling berdasarkan lokasi penelitian. Pengambilan data dilakukan dimana, konduktivitas dan salinitas berada pada berbagai keadaan perairan guna mewakili berbagai keadaan yang sebenarnya pada lautan.

Verifikasi koefisien penting dilakukan untuk mengetahui apakah koefisien ini berlaku sama untuk semua data salinitas yang telah dikonversi ke dalam TDS. Verifikasi dilakukan dengan uji statistika dan penerapan koefisien melalui hubungan linieritasnya, dan untuk mendapatkan koefisien hubungan antara konduktivitas dengan salinitas sebagai keterwakilan kandungan TDS, maka data pengukuran in-situ terhadap kedua parameter tersebut pada lokasi sampling sangat di perlukan, adapun titik sampling yang diperkirakan memiliki koefisien hubungan, diinformasikan pada Gambar 2, sedangkan data yang digunakan untuk masing-masing titik sampling adalah pada kedalaman 0 - 10 meter. Adapun dasar dari ditentukannya koefisien konduktivitas pada kedalam

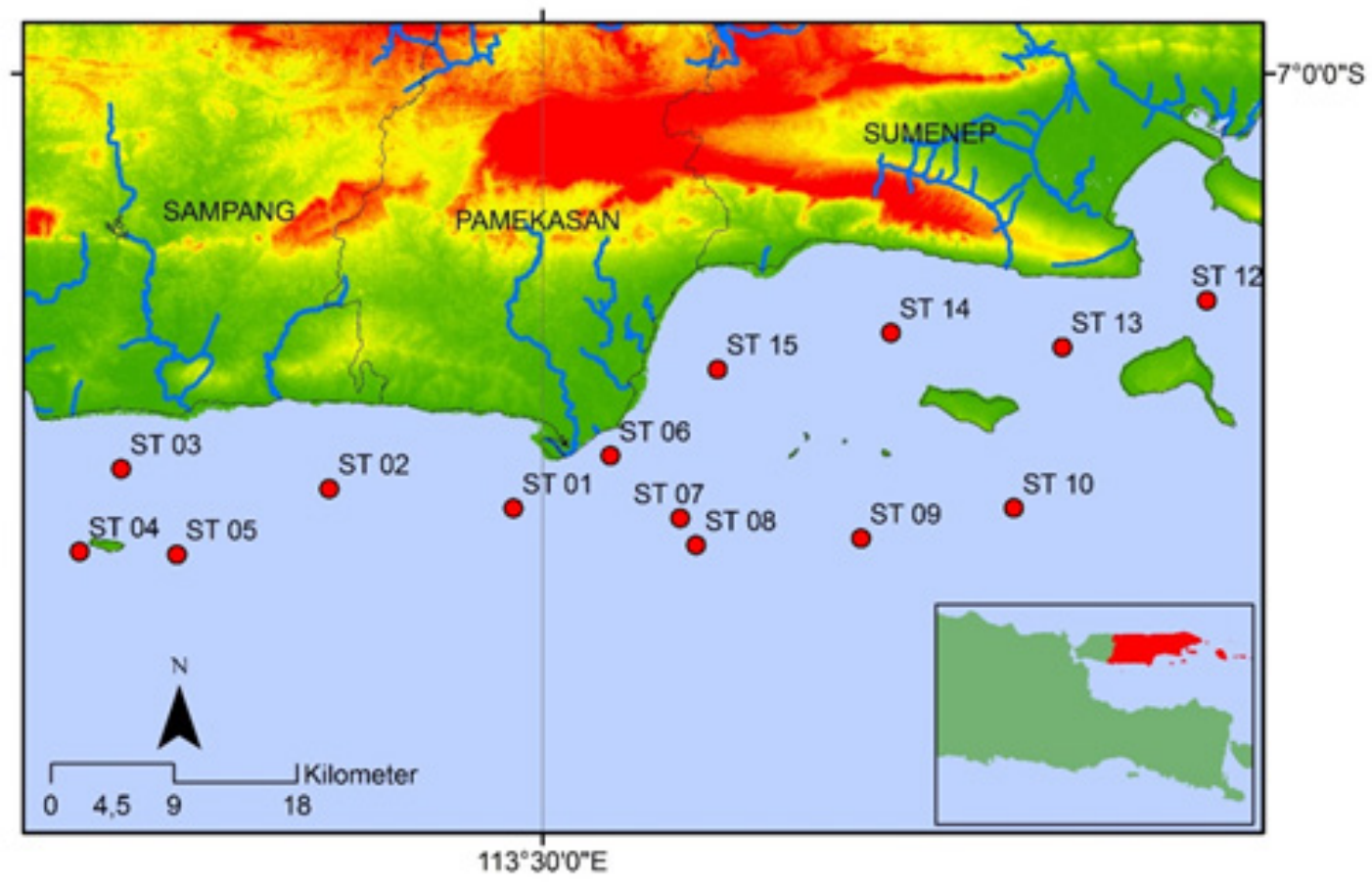

Gambar 1. Titik pengukuran konduktivitas menggunakan CTD.

Figure 1. Conductivity measurement point using CTD. 


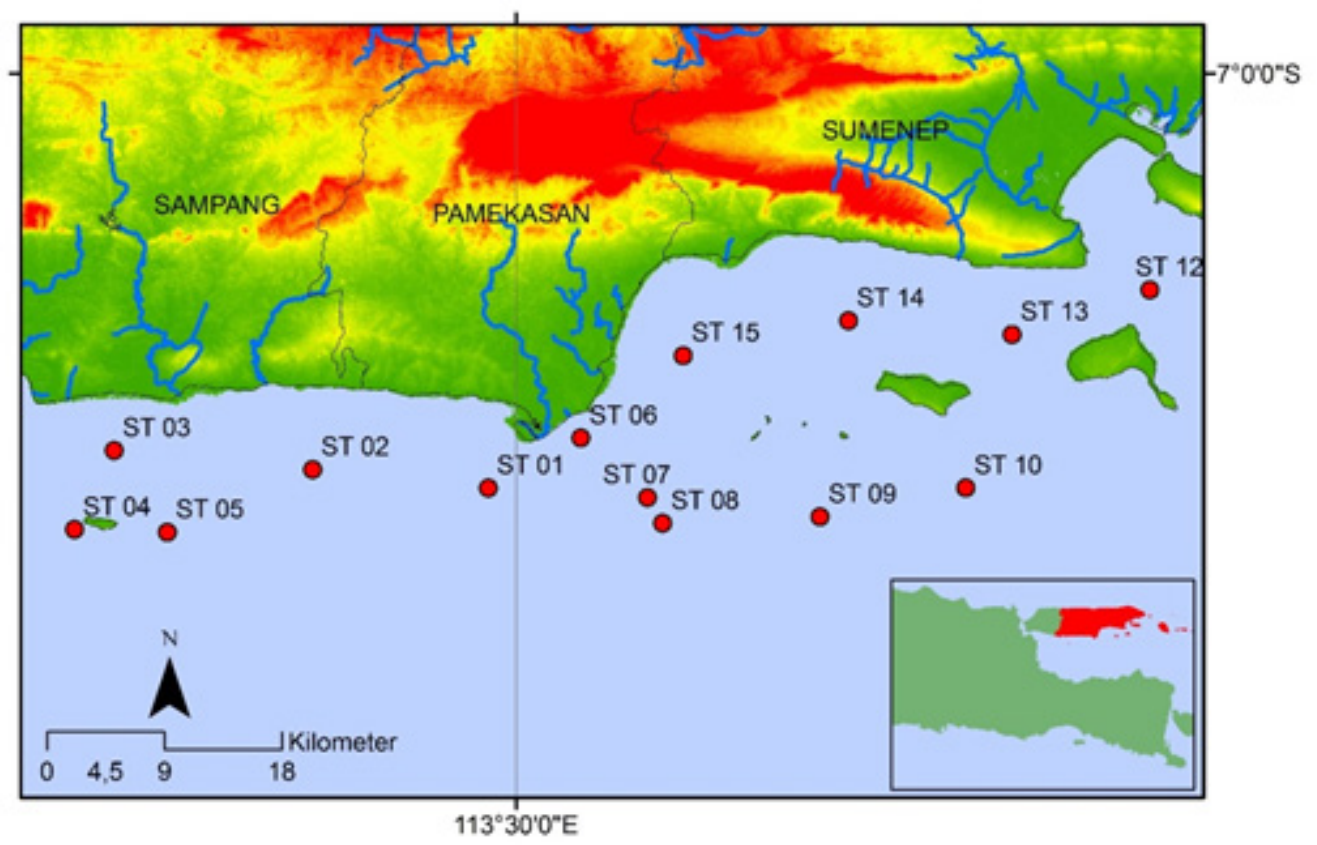

Gambar 2. Stasiun pengukuran untuk kajian Koefisien Konduktivitas dan TDS.

Figure 2. Measuring station for Conductivity Coefficient and TDS . study.

0 - 10 meter, karena keadaan air laut dan temperatur perairan pada kedalaman tersebut masih bisa dikatakan homogen. Selanjutnya untuk data TDS yang diperoleh, dilihat sebarannya pada perairan Selatan Pulau Madura dengan menggunakan perangkat lunak Ocean Data View (ODV) versi 4.5.6. (Schlitzer (2016))

Selanjutnya melalui persamaan (1) dan (2), koefisien konduktivitas pada masing-masing kedalaman dapat ditentukan. Untuk mengetahui koefisien tersebut dapat digunakan pada seluruh perairan maka dilakukan verifikasi melalui uji statistik terhadap koefisien pada kedalaman yang telah ditentukan.

\section{HASIL DAN PEMBAHASAN}

\section{Korelasi salinitas, TDS \& konduktivitas}

Konduktivitas (daya hantar listrik) merupakan kemampuan air untuk menghantarkan aliran listrik.
Daya hantar listrik tersebut lebih dipengaruhi oleh mineral terlarut dalam air terutama garam-garam yang terionisasi, yang berbanding lurus dengan daya hantar listrik (Effendi, 2003). Konduktivitas dinyatakan dalam satuan $\mu \mathrm{mhos} / \mathrm{cm}$ atau $\mu$ Siemens $/ \mathrm{cm}$. Konduktivitas memiliki kaitan erat dengan jumlah padatan terlarut (Total Dissolved Solid) (Tebbut, 1992).

Untuk mendapatkan hubungan antara data salinitas dan konduktivitas, pengukuran salinitas dilakukan. Data salinitas ini digunakan untuk mewakili analogi dari TDS, mengingat bahwa TDS merupakan sebagian besar berasal dari garam-garam anorganik yang terlarut, yang sebanding dengan salinitas. Melalui persamaan (1) dan (2), dapat diperoleh nilai koefisien konduktivitas pada kedalaman yang telah ditentukan sebelumnya yaitu kedalaman 0 meter dan 10 meter. Nilai koefisien konduktivitas pada masing-masing stasiun yang telah ditentukan, ditunjukkan dalam Tabel 1.

Tabel 1. Luasan sebaran sedimentasi

Table 1. Extent of Sedimentation Distribution

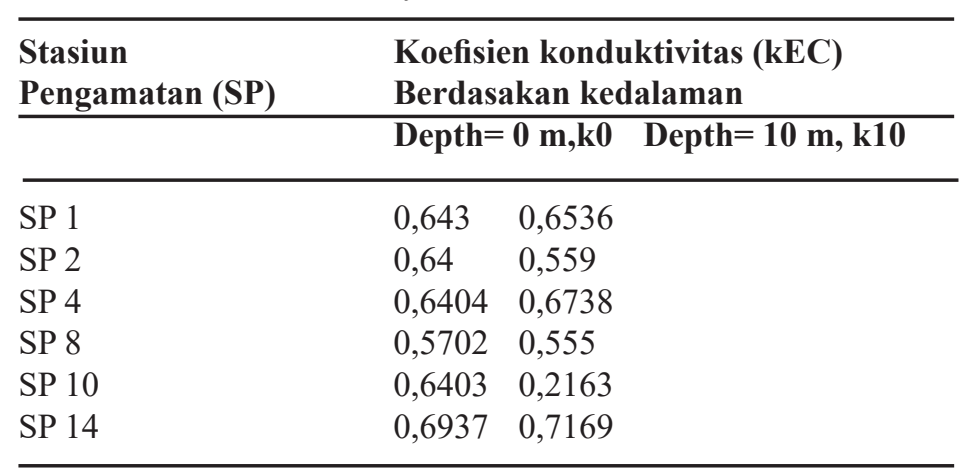


Untuk memperoleh koefisien yang valid dan dapat digunakan pada seluruh badan perairan di Selatan Pulau Madura, dilakukan verifikasi memalui uji statistik terhadap nilai koefisien tersebut. Uji statistik dilakukan dengan menggunakan ANOVA. Uji ini dapat membuktikan adanya perbedaan yang nyata atau tidak pada setiap koefisien konduktivitas. Perhitungan statistik antar koefisien yang diperoleh pada masingmasing kedalaman, ditunjukkan dalam Tabel 2.

Dalam Tabel 2 ditunjukkan bahwa nilai $\mathrm{P}$ adalah 0,33 dan dapat dikatakan tidak beda nyata karena nilai $\mathrm{P}>$ 0,5 . Berdasarkan hasil perhitungan statistik diatas maka dapat disimpulkan koefisien pada kedalaman 0 dan $10 \mathrm{~m}$ adalah tidak beda nyata. Adapun perbandingan nilai koefisien kedalaman $0-10 \mathrm{~m}$ pada stasiun terpilih, ditunjukkan dalam Tabel 3. Tanda superscript (a) merupakan tanda bahwa koefisien tersebut tidak terjadi beda nyata. Jika hasil uji statistik menunjukan tidak beda nyata maka koefisien dapat digunakan untuk stasiun lainnya. Hasil perhitungan diperoleh nilai rerata koefisien EC sebesar 0,64. Nilai tersebut selanjutnya diolah dengan data konduktivitas untuk mendapatkan
TDS pada lokasi studi.

Verifikasi juga dilakukan dengan menguji hubungan linieritas konduktivitas terhadap salinitas untuk memperoleh nilai koefisien konduktivitas. Uji linearitas dilakukan untuk melihat antara variabel satu dengan variable lainnya mempunyai hubungan yang linear atau tidak (Utami (2017)). Uji linearitas di gunakan untuk memilih model regresi yang akan digunakan. Uji linearitas dimaksudkan untuk mengetahui ada tidaknya hubungan secara linear antara variabel dependen terhadap setiap variabel independen yang hendak diuji. Jika suatu model tidak memenuhi syarat linearitas maka model regresi linear tidak bisa digunakan. Untuk menguji linearitas suatu model dapat digunakan uji linearitas dengan melakukan regresi terhadap model yang ingin diuji. Aturan untuk keputusan linearitas dapat dengan membandingkan nilai signifikansi dari Deviation from linearity yang dihasilkan dari uji linearitas dengan nilai alpha yang digunakan. Jika nilai signifikansi dari Deviation from Linearity $>$ alpha $(0,05)$ maka nilai tersebut linear (Sudarmanto (2005) dalam Djazari et al. (2013)).

Tabel 2. Perhitungan ANOVA pada kedalaman terpilih, yaitu kedalaman 0 dan $10 \mathrm{~m}$ Table 2. ANOVA calculation at selected depths, namely 0 and $10 \mathrm{~m}$ depth

Anova: Single Factor

SUMMARY

\begin{tabular}{rrrrrr}
\hline \multicolumn{1}{c}{ Groups } & \multicolumn{1}{c}{ Count } & \multicolumn{1}{c}{ Sum } & Average & Variance \\
\hline 0.643 & 5 & 3.1846 & 0.63692 & 0.001927 \\
0.6536 & 5 & 2.7218 & 0.54436 & 0.038623 \\
\hline
\end{tabular}

\begin{tabular}{|c|c|c|c|c|c|c|c|}
\hline Source of Variation & SS & $d f$ & & $M S$ & $\bar{F}$ & P-value & F crit \\
\hline Between Groups & 0.021418 & & 1 & 0.021418 & 1.056382 & 0.334112 & 5.317655 \\
\hline Within Groups & 0.162202 & & 8 & 0.020275 & & & \\
\hline Total & 0.18362 & & 9 & & & & \\
\hline
\end{tabular}

Tabel 3. Perbandingan koefisien setelah perhitungan ANOVA.

Table 3. Comparison of coefficients after calculation of ANOVA

\begin{tabular}{lll}
\hline Stasiun & Koefisien 0 m & Koefisien 10 m \\
\hline SP 1 & 0,643 (a) & $0,6536(a)$ \\
SP 2 & $0,64(a)$ & $0,559(a)$ \\
SP 4 & $0,6404(a)$ & $0,6738(a)$ \\
SP 8 & $0,5702(a)$ & $0,6431(a)$ \\
SP 10 & $0,6403(a)$ & $0,6446(a)$ \\
SP 14 & $0,6937(a)$ & $0,7169(a)$ \\
\hline
\end{tabular}




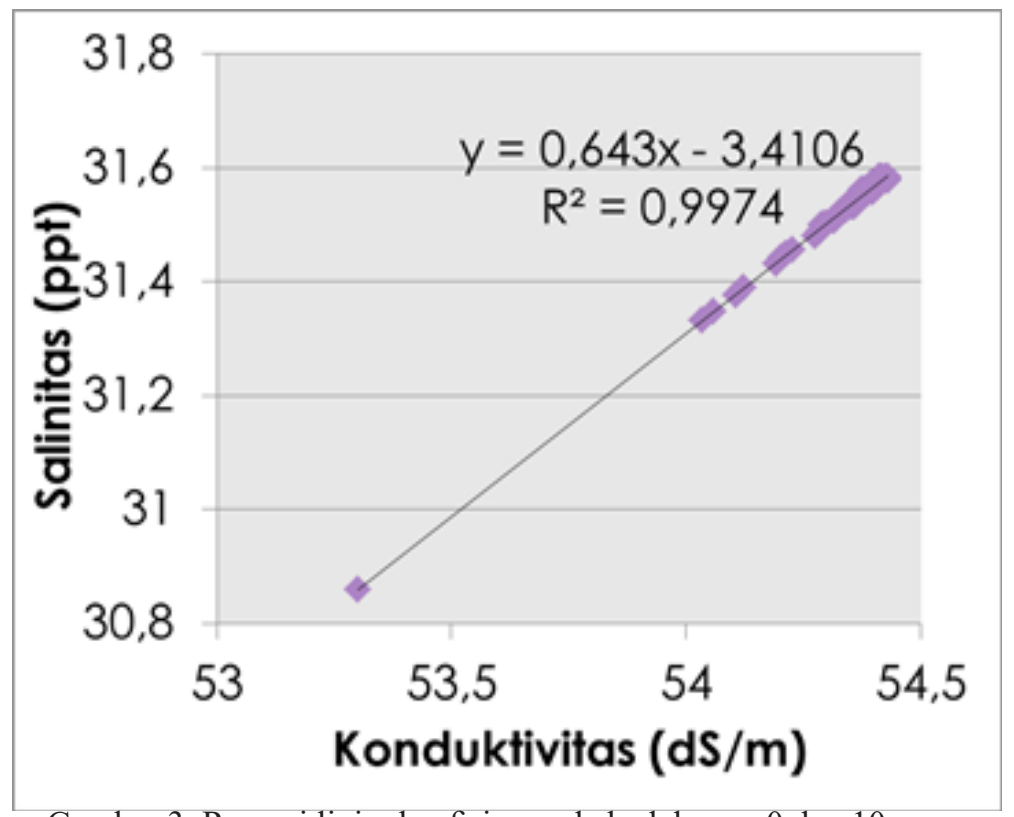

Gambar 3. Regresi linier koefisien pada kedalaman 0 dan $10 \mathrm{~m}$.

Figure 3. Linear regression coefficient at depths of 0 and $10 \mathrm{~m}$.

Uji linieritas ini dilakukan menggunakan data pada stasiun 1, dengan kedalaman 0 dan 10 m (Gambar 3).

\section{Profil TDS}

Data TDS yang diperoleh, dilihat sebarannya pada perairan Selatan Pulau Madura dengan menggunakan perangkat lunak Ocean Data View (ODV) versi 4.5.6. Schlitzer (2016)

Pada Gambar 4 disebutkan bahwa pada lapisan permukaan, besaran kandungan TDS yang tersebar di perairan Selat Madura yang merupakan perairan semi tertutup ini, berada dalam rentang 33,800-35,000 ppm. Pada lapisan permukaan ini terlihat variabilitas nilai kandungan TDS yang sedikit beragam. Kandungan TDS ter rendah berada di perairan Kabupaten Sampang, dengan nilai kandungan 33,800 ppm atau setara dengan salinitas 33,0 ppt, seperti yang terlihat pada Gambar 4 dengan warna ungu cerah hingga gelap. Hal ini menunjukkan bahwa daya hantar listrik pada area ini paling rendah jika dibandingkan dengan area lain pada perairan Selat Madura. Menurut Bengen (2002), wilayah pesisir sangat dipengaruhi oleh aktifitas manusia seperti industri dan rumah tangga, sehingga

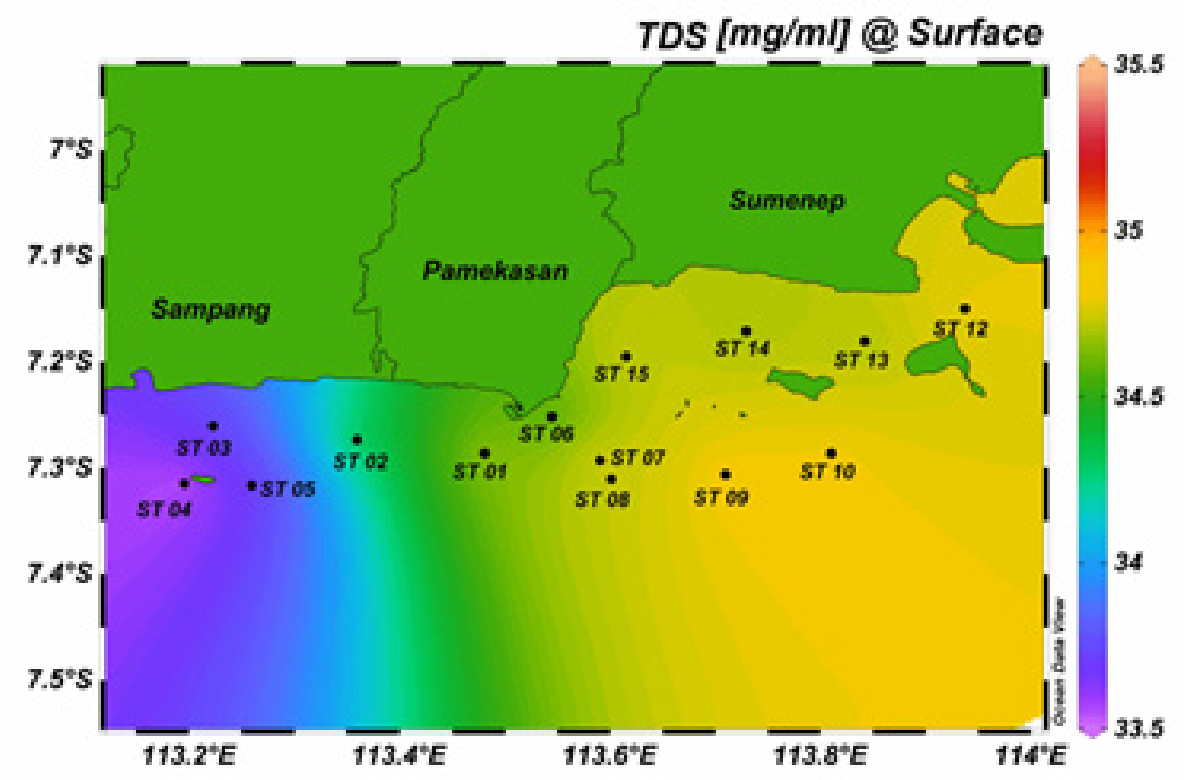

Gambar 4. Sebaran TDS pada permukaan.

Figure 4. Distribution of TDS on the surface. 


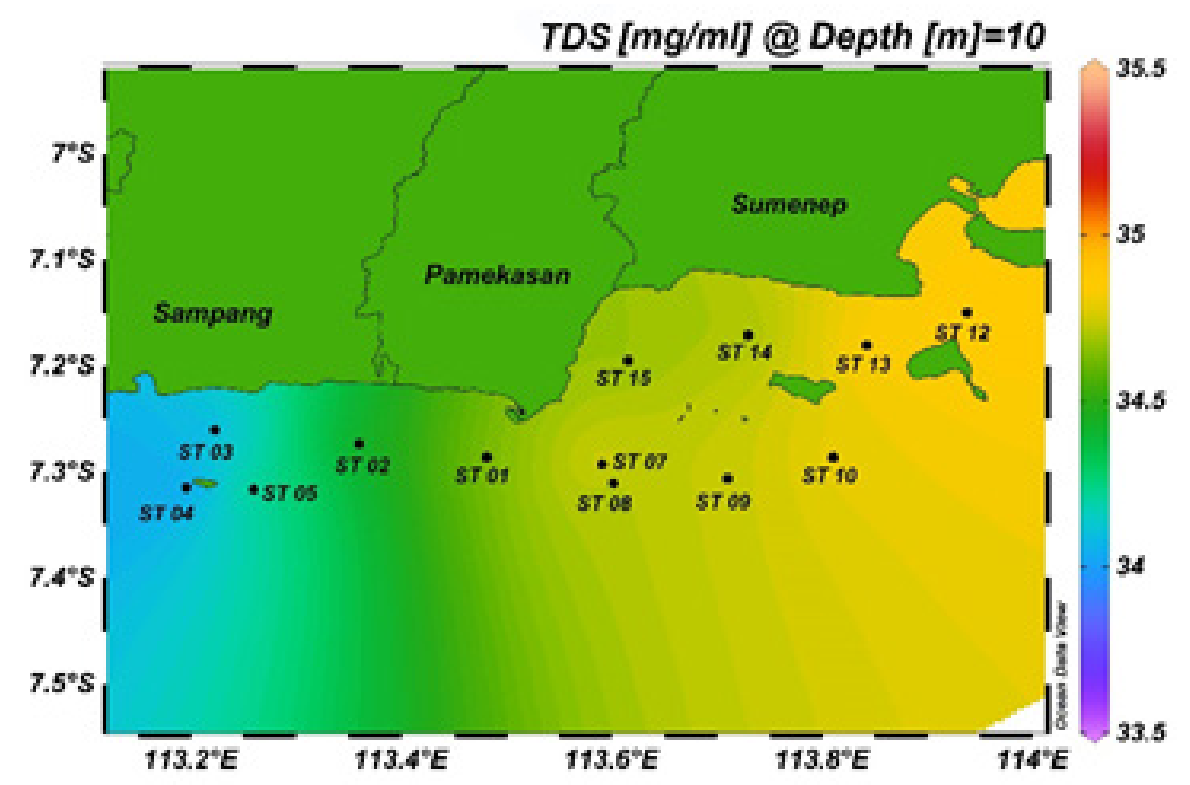

Gambar 5. Sebaran TDS pada kedalaman 10m.

Figure 5. Distribution of TDS at a depth of $10 \mathrm{~m}$.

menyebabkan daerah tersebut rentan terhadap perubahan kondisi lingkungan. Adanya pengaruhpengaruh dari lingkungan sekitar yang masuk ke perairan laut Kabupaten Sampang, menjadikan penyebab utama kondisi ini terjadi. Keberadaan sungai besar serta aktifitas manusia di Pulau Mandangin merupakan penyumbang terbesar air tawar dan limbah industri maupun rumah tangga pada perairan ini, sehingga proses pengadukan yang terjadi pada perairan permukaan kurang sempurna. Adapun pada perairan lapisan permukaan Kabupaten Pamekasan, nampak pada Gambar 4 ditunjukkan dengan gradasi warna dari hijau hingga kuning, dimana sesuai legenda nilai TDS 34,500-34,800 ppm atau setara dengan salinitas 34,5-34,8 ppt, sedangkan pada perairan Kabupaten Sumenep, nampak sebaran warna kuning tua merata yang menunjukkan nilai TDS 34,800-35,000 ppm atau setara dengan salinitas 34,8-35 ppt, dengan nilai konduktivitas rerata $54,349 \mu$ Siemens $/ \mathrm{cm}$. Adanya inlet sungai yang mengarah ke Selat Madura, serta terdapat beberapa pulau kecil di depan Kabupaten Sumenep tidak berpengaruh banyak terhadap proses pengadukan. Gradien tekanan massa air laut Flores yang masuk ke Selat Madura lebih mendominasi proses pengadukan perairan tersebut.

Gambar 5 memperlihatkan kandungan TDS pada kedalaman $10 \mathrm{~m}$ memiliki pola yang hampir sama dengan pola sebaran TDS di permukaan, hal ini bisa terjadi dikarenakan kurang sempurnanya proses pencampuran air laut pada kedalaman tersebut. Nilai kandungan TDS pada kedalaman $10 \mathrm{~m}$ di perairan
Selat Madura dari Kabupaten Sampang, Kabupaten Pamekasan hingga Kabupaten Sumenep, berada pada rentang 34,200-35,000 ppm atau setara dengan salinitas 34-35 ppt, dengan nilai kandungan terkecil berada pada Kabupaten Sampang seperti ditunjukkan dengan warna biru, dan yang tertinggi berada pada Kabupaten Sumenep, dengan warna kuning seperti yang terlihat di gambar 5. Akses masuknya massa air dari laut Flores ke selat Madura, dengan perairan Selatan Kabupaten Sumenep sebagai mulut sisi Timur selat Madura memungkinkan karakter massa air laut yang ada di perairan Kabupaten Sumenep masih merupakan karakter laut Flores. Adapun massa air laut pada perairan Kabupaten Sampang merupakan pencampuran dari massa air laut yang mengalir dari Selat Surabaya yang banyak tercampur air tawar dari sungai-sungai besar di Gresik, Surabaya dan Sidoarjo dengan massa air laut Flores yang cenderung terdegradasi kualitas mineralnya. hal ini didukung dalam penelitian PT. Santos Untuk Amdal Tahun 2004.

Pada kedalaman $15 \mathrm{~m}$, sebaran spasial TDS sedikit berubah dari lapisan sebelumnya, namun masih memiliki pola yang sama dengan 2 lapisan diatasnya. Kemungkinan telah terjadi proses pencampuran, namun keadaan - keadaan lingkungan sekitar masih mempengaruhi. Nilai kandungan TDS yang diperoleh sebesar 34,005 ppm hingga 35,000 ppm, dengan kandungan nilai TDS terkecil berada di perairan Kabupaten Sampang, seperti terlihat di gambar 6 dengan warna biru, sedangkan yang paling tinggi kandungan TDS nya ditunjukkan dengan warna kuning, 


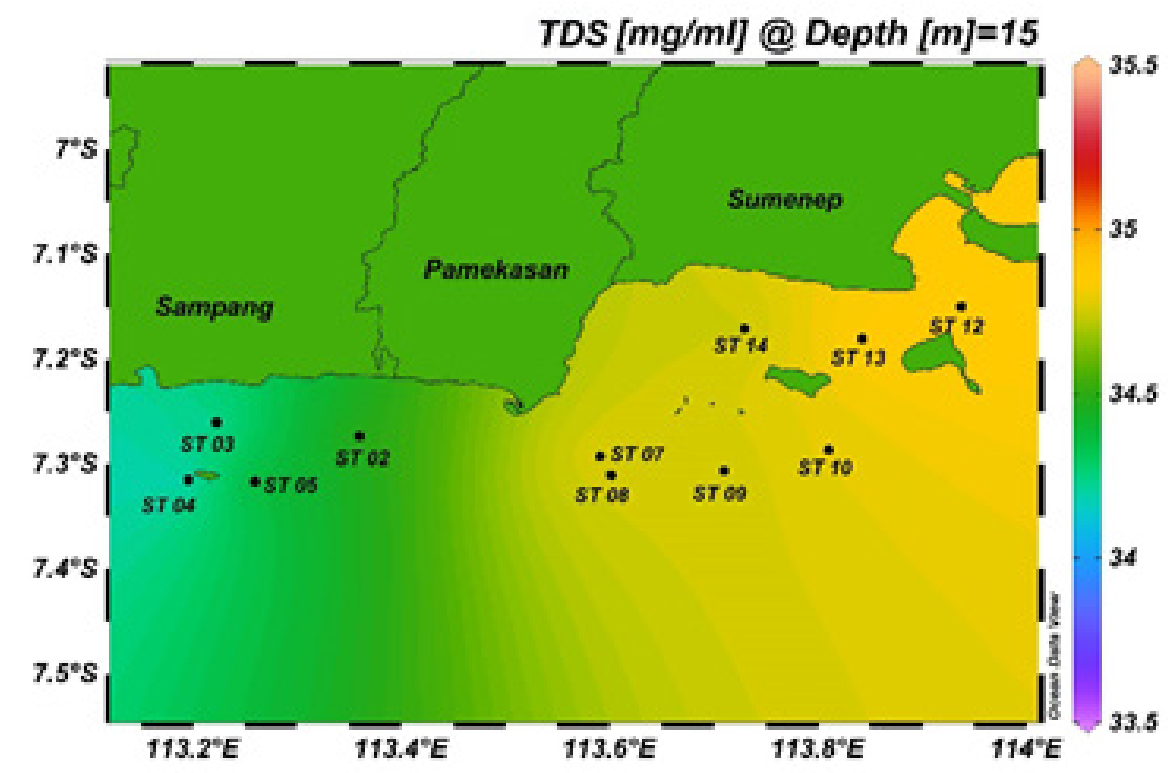

Gambar 6. Sebaran TDS pada kedalaman $15 \mathrm{~m}$.

Figure 6. Distribution of TDS at a depth of $15 \mathrm{~m}$.

berada di perairan Kabupaten Sumenep (Gambar 6)

Di kedalaman $20 \mathrm{~m}$ sebaran spasial TDS memiliki nilai yang hampir sama di semua stasiun pengamatan (Gambar 7), kemungkinan hal ini disebabkan oleh kurangnya pengaruh aktivitas dari daratan serta didukung gradien tekanan massa air laut Flores yang masuk Selat Madura cukup kuat pada kedalaman ini, yang menjadikan proses pencampuran sempurna sehingga kandungan TDS menjadi lebih besar yaitu berkisar antara $34,687 \mathrm{ppm}$ hingga $35,000 \mathrm{ppm}$. Variasi nilai kandungan TDS terrendah berada di perairan
Kabupaten Sampang, ditunjukkan dengan warna hijau kekuningan, sedangkan yang tertinggi pada perairan Kabupaten Sumenep dengan dominansi warna kuning tua, seperti yang terlihat pada gambar 7 .

Gambar 8 menunjukkan bahwa pada kedalaman $25 \mathrm{~m}$ sebaran spasial TDS hampir homogen, hal ini dikarenakan korelasi antara kandungan TDS dengan temperatur lebih dominan. Kisaran kandungan TDS pada kedalaman ini adalah sebesar $34,836 \mathrm{ppm}$ hingga 35,039 ppm. dengan variasi kandungan terrendah berada pada Kabupaten Sampang dan yang tertinggi

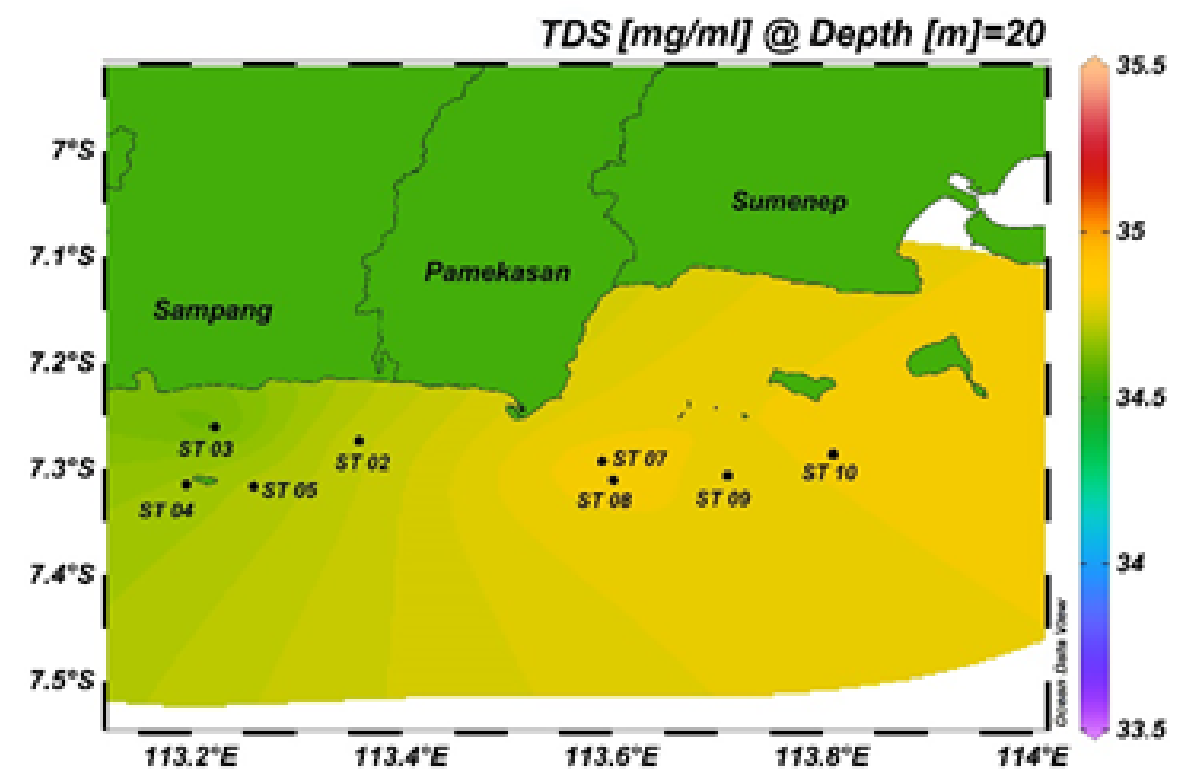

Gambar 7. Sebaran TDS pada kedalaman 20m.

Figure 7. Distribution of TDS at a depth of $20 \mathrm{~m}$. 


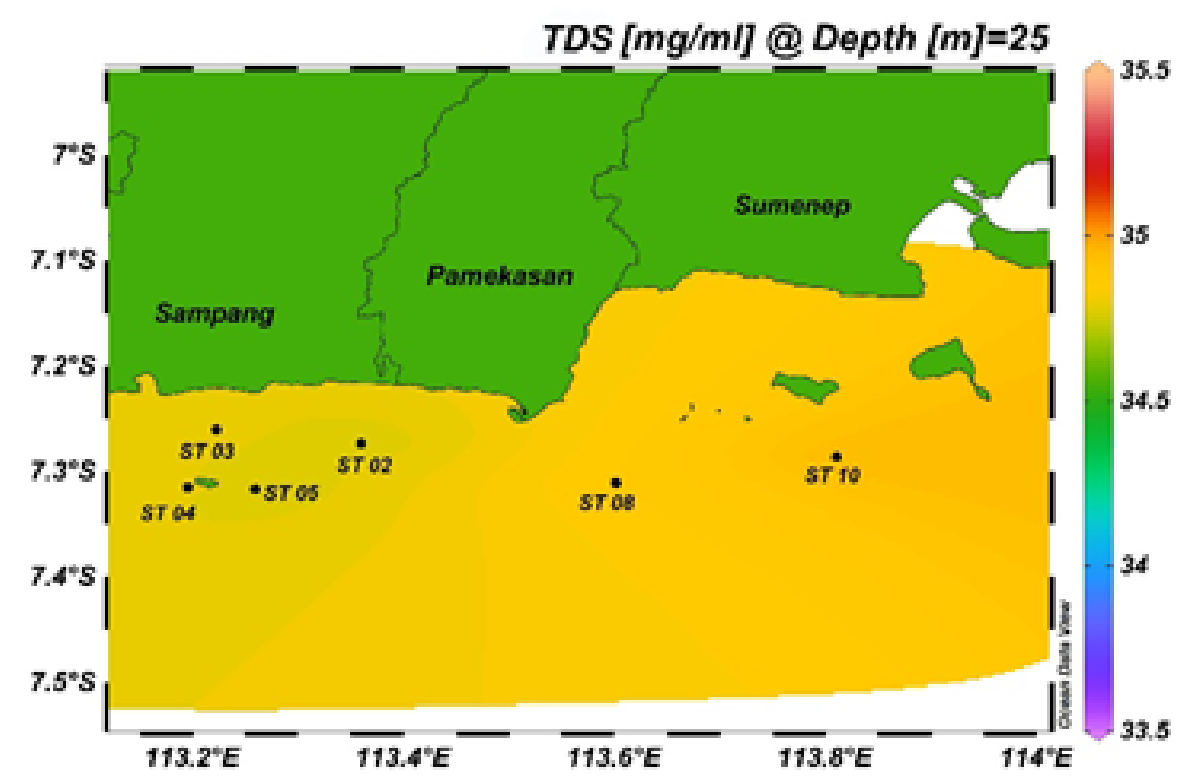

Gambar 8. Sebaran TDS pada kedalaman $25 \mathrm{~m}$.

Figure 8. Distribution of TDS at a depth of $25 \mathrm{~m}$.

pada Kabupaten Sumenep. Dilihat dari tingginya nilai TDS pada kedalaman ini ada kemungkinan faktor musim sangat mempengaruhi, seperti yang dilaporkan Pusat Penelitian dan Pengembangan Sumber Daya Laut dan Pesisir (P3SDLP) tahun 2013, bahwa Salinitas di Selat Madura pada Maret hingga Mei (termasuk musim peralihan I) bervariasi sekitar 29,5-32,5\%0 ,selanjutnya pada bulan September-November (musim peralihan II) meningkat yaitu antara 32,80-35\%o

Pada kedalaman 30 m kandungan TDS hampir sama besar, namun bila dicermati lebih dalam pada Gambar
9 terlihat ada satu stasiun yang nilainya lebih kecil dibandingkan sekelilingnya, kemungkinan hal ini disebabkan outlet dari sungai di sekitar kabupaten sampang. Hal ini juga diungkapkan oleh PT. SANTOS, (2004) bahwa, Tingginya BOD di Pantai Camplong diduga berhubungan dengan banyaknya masukan air sungai ke perairan ini. Air sungai tersebut membawa bahan organik baik tersuspensi maupun terlarut masuk ke perairan pantai tersebut. Hal ini berkaitan dengan adanya pengenceran, pada saat pasang volume perairan pantai menjadi lebih besar karena tambahan air dari laut yang relatif memiliki nilai BOD lebih rendah.

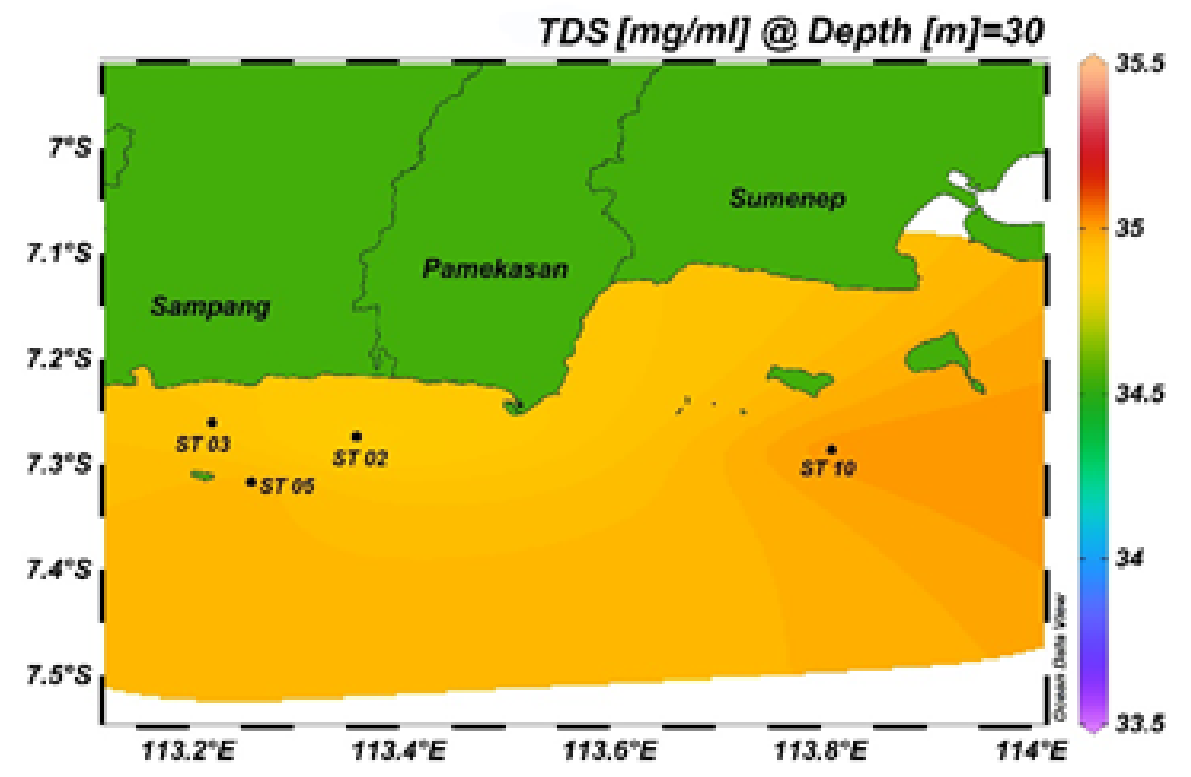

Gambar 9. Sebaran TDS pada kedalaman 30m.

Figure 9. Distribution of TDS at a depth of $30 \mathrm{~m}$. 


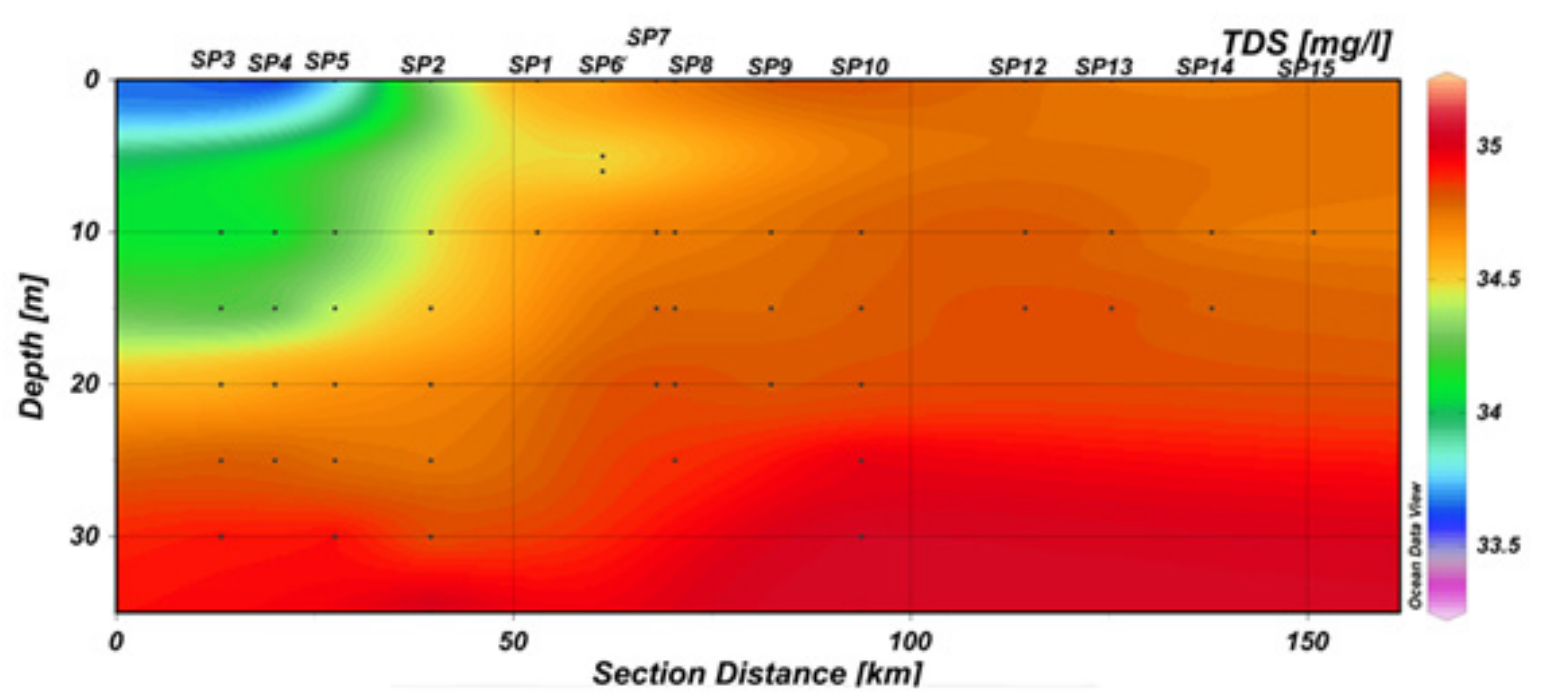

Gambar 10. Sebaran TDS secara vertikal di semua stasiun.

Figure 10. Vertical distribution of TDS in all stations.

Adapun kisaran kandungan TDS pada kedalaman ini sebesar 34.700 ppm - 35.000 ppm. Kandungan TDS juga meningkat seiring dengan menurunnya temperatur.

\section{Stratigrafi Sebaran TDS}

Berdasarkan Gambar 10 yang menggambarkan sebaran TDS secara vertikal di semua stasiun, dapat disampaikan bahwa kandungan TDS turut dipengaruhi oleh keadaan sekitar. Stasiun 3 hingga 5 merupakan stasiun pengamatan yang dekat daratan sehingga masih terpengaruh dengan aliran sungai, yang menjadikan kandungan TDS pada stasiun tersebut rendah. Selain keadaan lingkungan sekitar, temperatur turut mempengaruhi kandungan TDS pada badan perairan tersebut, hal ini ditunjukkan dengan semakin turun temperatur perairan maka semakin tinggi pula kandungan TDS yang ada. Kondisi ini diperkuat oleh Prasetyo \& Siswanto, (2014), yang menyatakan bahwa profil sebaran suhu perairan selatan Kabupaten Sampang relative normal dan homogen dengan fluktuasi relatif kecil, sehingga memudahkan biota untuk beradaptasi dan berkembang biak. Stasiun yang jauh dari pesisir, nilai salinitas tinggi ini dapat disebabkan oleh asupan massa air dari laut yang lebih tinggi. Nilai salinitas yang lebih rendah berada di stasiun yang dekat dengan pesisir dan muara sungai. Salinitas yang lebih rendah disebabkan adanya asupan air tawar dari mulut sungai yang bercampur di daerah muara.

\section{KESIMPULAN DAN SARAN}

\section{Kesimpulan}

Beberapa point kesimpulan yang diperoleh pada penelitian kali ini antara lain:
- Korelasi antara EC dan Salinitas di perairan Selat Madura, pada kedalaman 0 dan $10 \mathrm{~m}$ ditunjukkan dengan nilai koefisien rerata 0,64 , berarti di kedua kedalaman tersebut nilai koefisien tidak beda nyata, sehingga dapat digunakan sebagai acuan untuk menentukan besaran mineral terlarut/TDS.

- Pada kedalaman lebih dari $10 \mathrm{~m}$, korelasi EC dan salinitas di perairan Selat Madura terhadap jumlah mineral terlarut tidak berbanding lurus karena pengaruh temperatur dan tekanan di kedalaman perairan lebih dominan.

- Kondisi lingkungan sekitar mempengaruhi besaran TDS yang terkandung dalam air laut, terbukti dari beberapa hasil pengukuran yang menunjukkan bahwa perairan depan daratan, kandungan TDS lebih kecil dibandingkan dengan kandungan TDS yang berada di laut lepas.

\section{Saran}

Seringkali Konduktivitas menjadi salah satu metode praktis untuk menentukan jumlah mineral terlarut, namun perlu diperhatikan bahwa metode ini tidak sepenuhnya dapat digunakan pada berbagai macam perairan untuk menentukan jumlah padatan terlarut. Perlu adanya koreksi koefisien korelasi antara EC dan salinitas pada tiap-tiap perairan.

\section{UCAPAN TERIMA KASIH}

Penelitian ini merupakan bagian dari kegiatan Analisa Karakteristik Sumberdaya Air Laut Selat Madura yang menggunakan APBN yang ada di Pusat Penelitian dan Pengembangan Sumberdaya Laut dan Pesisir Tahun 2013. Seluruh penulis merupakan kontributor utama dalam artikel ilmiah ini. Penyusunan naskah artikel 
ilmiah ini dilakukan dengan diskusi secara daring sepanjang tahun 2020 - 2021. Ucapan terima kasih disampaikan pada DR. Ifan R Suhelmi, DR. Ahmad Najid, Muh. Ramdhan, M.Si, Triyono, M.T, Wahyu Hidayat, Riswan Hasan, Muh. Arofik S.Pi serta Heru Faizal, M.Si (Dinas Kelautan dan Perikanan Sumenep) yang telah membantu dalam pelaksanaan penelitian.

\section{DAFTAR PUSTAKA}

Afrianita, R., Edwin, T., \& Alawiyah, A. (2017). Analisis Intrusi Air Laut dengan Pengukuran Total Dissolved Solid (TDS) Air Sumur Gali di Kecamatan Padang Utara. Jurnal Teknik Lingkungan UNAND, 14(1), 62-72. DOI: https:// doi.org/10.25077/dampak.14.1.62-72.2017

Bengen, D.G. 2002. Ekosistem dan sumberdaya alam pesisir dan laut serta prinsip pengelolaannya. Sinopsis. Pusat Kajian Sumberdaya Pesisir dan Lautan. Institut Pertanian Bogor, Bogor.

Djazari, M., Rahmawati, D., \& Nugroho, M. A. (2013). Pengaruh sikap menghindari resiko Sharing dan Knowledge Self-Efficacy terhadap Informal Knowledge Sharing pada mahasiswa Fise UNY. Jurnal Nominal, 2(2), 181-209. DOI: https://doi. org/10.21831/nominal.v2i2.1671

Effendi, H. (2003). Telaah Kualitas Air: Bagi Pengelolaan Sumber Daya dan Lingkungan Perairan. Jakarta. Kanisius.

Gasim, M. B., Nadila A.K., \& Haniff, M. (2015). The Influence of Tidal Activities on Water Quality Of Paka River Terengganu, Malaysia. Malaysian Journal of Analytical Science, 19(5), 979-990.

Izati, N., \& Syech, R. (2020). Analisis Pengaruh Resapan Air Laut Terhadap Intrusi Air Sumur Gali Desa Jangkang Kabupaten Bengkalis Komunikasi Fisika Indonesia, 17(1), 7-13. DOI: http://dx.doi.org/10.31258/jkfi.17.1.7-13.

Khairunnas, K., \& Gusman, M. (2018). Analisis Pengaruh Parameter Konduktivitas, Resistivitas dan TDS Terhadap Salinitas Air Tanah Dangkal pada Kondisi Air Laut Pasang dan Air Laut Surut di Daerah Pesisir Pantai Kota Padang. Jurnal Bina Tambang 3(4), 1751-1760.

Litaay, M., Amiruddin, A., Fauziah, S., \& Budi, R.
(2014). Bahan Ajar Oseanologi Pendahuluan. Makassar : Universitas Hasanuddin.

McNeely, R. N., Neimanis, V. P., \& Dwyer, L. (1979). Water Quality Sourcebook: A Guide to Water Quality Parameters. Environmental Canada Publications.

Mutmainah, H., \& Adnan, I. (2018). Status Kualitas Perairan Kawasan Terpadu Pelabuhan Perikanan Samudera Bungus Menggunakan Metode Indeks Golongan Air. Jurnal Teknologi Lingkungan, 19(1), 107-116. DOI: https://doi.org/10.29122/ jtl.v19i1.2030

Nurrohim, A., Sanjoto T. B., \& Setyaningsih, W. (2012). Kajian Intrusi Air Laut di Kawasan Pesisir Kecamatan Rembang Kabupaten Rembang. Geo Image, 1(1), 22-27. DOI: https:// doi.org/10.15294/geoimage.v1i1.942

Prasetyo, E. B., \& Siswanto, A. D. (2014). Variabilitas suhu dan salinitas di perairan Selat Madura. Prosiding Seminar Nasional Hasil Penelitian Perikanan dan Kelautan III. Jurusan Ilmu Kelautan, Fakultas Perikanan dan Ilmu Kelautan, Universitas Diponegoro, Semarang, hal 119-122.

SANTOS. (2004). ANDAL Pengembangan Lapangan Oyong dan Lapangan Maleo dan Pemasangan Pipa Bawah Laut di Selat Madura, Jawa Timur, Jakarta 2004.

Schlitzer, R. (2016). Ocean Data View, https://odv.awi. de.

Shirokova, Y., Forkutsa, I dan Sharafutdinova, N. (2000). Use of electricity conductivity instead of soluble salts for soil salinity monitoring in central Asia. Irrigation and drainage Systems, 14(3), 199-206. DOI: 10.1023/A:1026560204665

Siosemarde, M., Kaveh, F., Pazira, E., Sedghi, H., \& Ghaderi, S. J. (2011). Evaluation of empirical models to relate sum cationic concentration to electrical conductivity in saltaffected soils. Journal of Food, Agriculture \& Environment, 9(1), 465-468. DOI: https://doi. org/10.1234/4.2011.1989

Sudarmanto, R. G, (2004). Analisis Regresi Linear Berganda Dengan SPSS, Graha Ilmu, 2004. 
Tebbutt, T. H. Y. (1992). Organic Geochemistry of Natural Waters. Mrtinus Nijhoff/Dr.W.Junk. Publ, Dordrecht, The Netherlands .

Thirumalini, S., \& Joseph, K. (2008). Correlation between Electrical Conductivity and Total Dissolved Solids in Natural Waters. Malaysian Journal of Science, 28(1), 55-61. DOI: https:// doi.org/10.22452/mjs.vol28no1.7

Utami, A. R. (2017). Verifikasi Metode Pengujian Sulfat dalam Air dan Air Limbah Sesuai SNI 6989.20 : 2009. Jurnal Teknologi Proses dan Inovasi Industri, 2(1), 19-25. DOI: http://dx.doi. org/10.36048/jtpii.v2i1 